\title{
SARS-Cov2 enables anaerobic bacteria (Prevotella, et al) to colonize the lungs disrupting homeostasis, causing long-drawn chronic symptoms, and acute severe symptoms (ARDS, septic shock, clots, arterial stroke) which finds resonance, with key differences, in the 'forgotten disease' Lemierre Syndrome, enabled by Epstein Barr Virus
}

\author{
Sandeep Chakraborty
}

\begin{abstract}
Metagenomic studies of Covid19 patient sequencing data from different countries (China, Brazil, Peru, Cambodia, USA) shows a pattern that SARS-Cov2 enables anaerobic bacteria (eg Prevotella, Veillonella, Capnocytophaga, Fusobacterium, Oribacterium and Bacteroides) colonize the lungs, disrupting the homeostasis found in healthy patients. Long drawn symptoms in Covid19 have caused great consternation, and could be explained by persistence of biofilms. Some of these bacteria are implicated in increasing IL-6, cause ground glass opacity in lungs and are associated with cardiac injury - all symptoms associated with Covid19. Many studies also show several bacterial infection markers - like D-dimer, $\mathrm{LDH}, \mathrm{C}$-reactive protein and ferritin - being significantly high, while the viral immune response is attenuated (reported by three studies till date). This is also confirmed here in the lung sample from a 74 year old deceased patient, showing high levels of IFITM3, ferritin and S100 calcium binding protein. Anaerobic bacteria causing initial symptoms like persistent fever, chills, pain and later symptoms like ARDS, blood clots, arterial stroke and septic shock finds resonance in a "forgotten disease" - Lemierre syndrome (LS). While, LS is enabled by Epstein Barr Virus - possibly by 'a transient depression of T cell immunity', two recent studies show that IFN- $\lambda$ might promote bacterial superinfection in Covid19. Also, 16S rRNA bacterial genes and endotoxins (LPS) were discovered in 18/19 severely ill pneumonia patients in one study, suggesting dissemination of endotoxins, and not actual bacteria, might suffice to cause severity. Autopsies also show foci of acute bronchopneumonia. There are key differences with LS - for example origin of LS is the jugular vein while Covid19 starts in the lungs (and this difference should result in Covid19 to be easier to treat). Co-infection of EBV and SARS-Cov2 leads to greater symptoms (fever, higher CRP) in a study of 67 patients. SARS-2003 showed a lot of similar symptoms, which did not get enough media attention. There was a specific warning issued in 2004 for 'an increased vigilance against stroke and other thrombotic complications among critically-ill SARS patients in future outbreaks'. Enhanced pathogen testing kits, which include RT-PCT for bacterial genes and endotoxin tests, could confirm this disruption in Covid19, and thus anaerobic-specific antibiotics could significantly help in therapy.
\end{abstract}




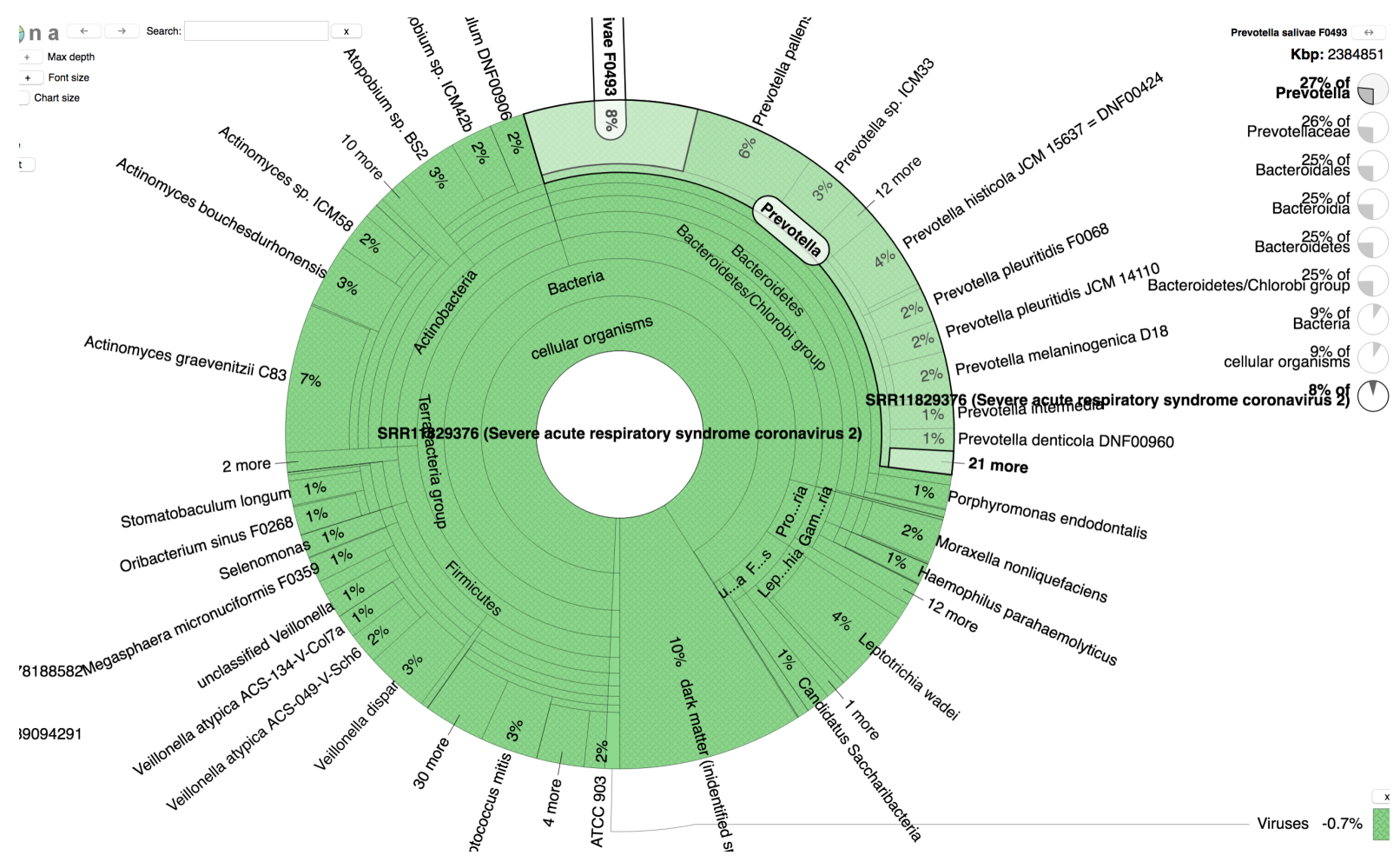

Figure 1: Krona figure generated from the NCBI analysis of a nasopharyngeal sample from Altanta, Georgia: The Prevotella abundance is visible (light green). Atopobium (5\%) of the reads is around 11 o'clock.

\section{Introduction}

Triggered by a novel strain of a coronavirus SARS-Cov2 [1] first detected in Wuhan City, the Covid19 pandemic [2] has spread globally like a wildfire [3].

As the death toll mounts, scientists and doctors have struggled to understand the underlying mechanism of the disease. Several clinical studies have defined a pattern observed in most patients - hypoxia (lack of oxygen), high D-dimers, high LDH, low lymphocyte counts, etc [4]. Also, several studies have reported high Procalcitonin, C-reactive protein and ferritin - markers for bacterial infections $[5,6]$. The success of trials using antibiotics (albeit supplemented with other therapies) indicates chances of a more prevalent bacterial role in severe cases [7]. This would not be a first - both the 1918 Spanish Flu [8] and 2003 SARS outbreak [9] had secondary infections as the primary causes of mortality.

Here, using sequencing data submitted in NCBI, I have analyzed the metagenomic composition of Covid19 patients from across the globe (the disease state remains unknown to me). Several of these have no published study on them yet. A pattern that emerges from this data is the prevalence of anaerobic bacteria, which seems to have been enabled by SARS-Cov2 to overcome homeostasis with aerobic counterparts. Some of these anaerobic bacteria are opportunistic pathogens - capable of producing the same symptoms observed in Covid19. Finally, I analyze the sequencing data from the lung sample of a 74 year deceased man, and demonstrate that markers for bacterial infections are high. 


\section{Results}

\section{Study1: China first study to publish the SARS-Cov2 genome, 29,903 nt GenBank accession number MN908947}

The RNA-seq data from Wuhan, China (PRJNA603194 [10]) has significant number of reads of Prevotella. SI Tables in the original paper show the abundance of the bacteria (although there is no mention of this in the main paper [10]), so this is not shown here.

However, the expression of bacterial proteins are analyzed. The expression levels (Table 2) shows that the elongation factor $\mathrm{Tu}$ is the most expressed. Although, 'elongation factor $\mathrm{Tu}$ (Tuf) is a new virulence factor of Streptococcus pneumoniae that binds human complement factors, aids in immune evasion and host tissue invasion' [11], controls are needed to ascertain whether this is over-expressed here (or generally high). Leaving aside immune suppression, the abundance of Prevotella could result in a cytokine storm, since its LPS is known to 'epithelial cells to produce IL-8, IL-6 and CCL20, which can promote mucosal Th17 immune responses and neutrophil recruitment' [12].

\section{Study2: Nanopore sequencing data from a familial cluster in Shenzhen}

In this study, the patients were tested for four bacterial species - Bordetella pertussis, Bordetella parapertussis, Chlamydophila pneumoniae, and Mycoplasma pneumoniae, which gave negative results. The sequencing data (Accid:SRR10948474, Nanopore, Table 3) shows a wide range of bacterial species - Lautropia, Cutibacterium, Haemophilus being most abundant. The presence of Campylobacter could explain diarrhea seen in the patient [13,14]. Also, their tests should have detected Mycoplasma - this demonstrates the sensitivity of NGS.

\section{Study3: 2 patients in Wuhan, failure to identify pathogenic bacteria using Metaphlan2}

One of the earliest studies publishing sequencing data (Illumina) from two SARS-Cov patients in Wuhan [15] wrote 'bacterial pathogen identification was carried out by using the Metaphlan2 program, which revealed Capnocytophaga sp and Veillonella sp in sample 2 and none in sample 1, and both bacteria identified were not known for their pathogenicity. Collectively, coronavirus is likely to be the main microbial pathogen' [15]. This is clearly incorrect - Capnocytophaga and Veillonella are there, and so are many other pathogenic species (Table 4).

\section{Study4: Very little viral load in five early patients from Wuhan}

The metagenome from the BALF of five Covid19 patients from Wuhan (Accid:PRJNA605983, Table 5) shows very little viral load (in the tens/million reads). This is a very plausible reason for false negatives, as there is just not enough virus to detect. Thus, it is important to have a bigger set of RT-PCR primers to cover more of the genome.

While there are a wide range of bacteria, Pseudomonas has definitely colonized patient1, while patient5 seems to have have the least bacterial load. Here, a closely related species Alloprevotella is also abundant in one patient [16].

\section{Study5: Patients from Peru and Cambodia - clear disruption of homeostasis:}

Here, two more studies from Peru and Cambodia (Table 6) provide further corroboration to the anaerobic bacteria theory. These anaerobic bacteria have virtually colonized the metagenome - pushing other aerobic species out of the niche, disrupting the homeostasis. Around $30 \%$ and $23 \%$ of the reads from Peru and 
Cambodia are bacterial, respectively. This is not observed in other patients, even when having chronic issues [17].

\section{Study6: Brazil, very low counts, do not add upto a single genome}

The metagenome from the nasopharyngeal swab of a suspected case of local transmission of Covid-19, in Brazil (Accid:PRJNA613951,reads=115933) was analyzed.

There are just 152 reads (out of 115933 reads) matching to SARS-Cov2 [18], which adds up a total of $21190 \mathrm{bp}$, much lesser than the 30000bp SARS-Cov2 genome. This is a very plausible cause for false negatives, there is just not enough virus to detect.

For eg, if the RT-PCR test was looking for a genomic fragment in the spike protein (3879bp) from 3691174 , it would not find a match. Thus, it is important to use multiple primers spread across the genome, something which the CDC test does not do.

There are a wide range of bacteria - Lautropia, Prevotella, Haemophilus dominating (Table 7).

\section{Study7: Metagenome from a Covid19 patient in Bangladesh shows Lawsonella clevelandensis - hard to culture anaerobic bacteria that causes abscesses}

While, bacterial load is low (and this might be due to removal of reads), it corroborates the anaerobic domination with a novel anaerobic bacteria - Lawsonella clevelandensis - being implicated (Accid:PRJNA633241, Table 8).

Lawsonella clevelandensis is a Gram-positive, partially acid-fast, anaerobic 'difficult to identify by conventional methods, leading to inappropriate treatments' [19]. The case reported is the 3 -week evolution of a breast nodule in 29-year-old woman. Cultures obtained from surgical drainage of the abscess went through a prolonged incubation period of 10 days, after which colonies were observed, and Lawsonella clevelandensis was confirmed by molecular methods. The therapy was changed to amoxicillin-clavulanic acid, and the abscess was successfully resolved without recurrence. Also, recently liver abscess was reported in a patient with rheumatoid arthritis [20]. Once again, cultures failed to grow the bacteria, and 16S rRNA PCR gene sequencing analysis confirmed Lawsonella clevelandensis. Treatment was changed to amoxicillin/clavulanic acid, and abscesses went away completely in 4 weeks. Another case of a 2-year-old girl (infected spinal dermoid cyst) caused by Lawsonella clevelandensis (surgical drainage followed by prolonged course of antibiotics), which again faced culturing issues [21].

Thus, inspite of low bacterial load, metagenome of a Covid19 patient from Bangladesh (most likely a child, since it was done in Child Health Research Foundation) shows the potential of anaerobic colonization, which I hypothesize is the cause of disease severity in Covid19.

\section{Study8: Metagenome from Atlanta, Georgia (US)}

The metagenome from a Covid19 patient in Emory University School of Medicine, Georgia is analyzed (Table 9, Fig 1). Prevotella/Streptococcus and other anaerobes colonize the nasopharyngeal metagenome (Accid:SRR11829376). Another sample (Accid:SRR11827437) shows Enterococcus colonization, and although the source of the sample is mentioned as nasopharyngeal swab, most of the bacteria are gut related (Table 9). Just as the Bangladesh metagenome had a new hard-to-culture anaerobe implicated in disease (Lawsonella), here Atopobium [22,23] is another anaerobe with significant abundance. Atopobium is implicated in bacterial vaginosis and 'around $80 \%$ of the cases and might be involved in therapeutic failure' [24]. BV biofilm formation, and antibiotic resistant A. vaginae could explain therapeutic failures and recurrences of BV [23]. Long drawn symptoms in Covid19 have caused great consternation, and could be similarly explained by persistence of biofilms [25]. Also, the synergy between Atopobium and Gardnerella Vaginalis is a key virulence factor implicated in disease, since G. vaginalis displaces protective lactobacill, and the initial colonization [26] establishes the biofilm structures to which secondary colonizers, such as A. vaginae attach. 
Table 1: Bacterial reads in sequencing data from nasopharyngeal swab (NSPH) or gut Submitted by Emory University School of Medicine, Georgia. Prevotella/Streptococcus and other anaerobes colonize the metagenome, corroborating the hypothesis that SARS-Cov2 is enabling anaerobes. The bacterial load is quite high, the first five species comprise $70 \%$ of the load.

\begin{tabular}{|c|c|c|c|c|}
\hline & PerMillion & Bacteria & Type & Diseases \\
\hline $\mathrm{NSPH}$ & $\begin{array}{c}218827 \\
202862 \\
191362 \\
66431 \\
33327 \\
23896 \\
23534 \\
15448 \\
12172 \\
9603 \\
8482 \\
7103 \\
6706 \\
6689 \\
4793\end{array}$ & $\begin{array}{c}\text { Veillonella } \\
\text { Prevotella } \\
\text { Streptococcus } \\
\text { Schaalia } \\
\text { Atopobium } \\
\text { Leptotrichia } \\
\text { Moraxella } \\
\text { Bacteroides } \\
\text { Actinomyces } \\
\text { Megasphaera } \\
\text { Porphyromonas } \\
\text { Campylobacter } \\
\text { Fusobacterium } \\
\text { Selenomonas } \\
\text { Lachnoanaerobaculum }\end{array}$ & $\begin{array}{c}\text { obligateanaerobic } \\
\text { obligateanaerobic } \\
\text { FAC-ANE } \\
\text { FAC-ANE } \\
\text { anaerobic } \\
\text { FAC-ANE } \\
\text { aerobic } \\
\text { obligateanaerobic } \\
\text { FAC-ANE } \\
\text { obligateanaerobic } \\
\text { obligateanaerobic } \\
\text { aerobic } \\
\text { obligateanaerobic } \\
\text { obligateanaerobic } \\
\text { anaerobic }\end{array}$ & $\begin{array}{c}\text { rare cases of meningitis, osteomyelitis, and periodontal disease }[27] \\
\text { aspiration pneumonia, lung abscess, pulmonary empyema, etc }[12,28] \\
\text { pneumonia, bacteremia }[29] \\
\text { similar to Actinomyces, alimentary tract diseases [30] } \\
\text { Bacterial vaginosis }[24] \\
\text { Endocarditis }[31] \\
\text { otitis media in infants and children [32] } \\
\text { 'genus Bacteroides have the most antibiotic resistance mechanisms' [33] } \\
\text { alimentary tract diseases [30] } \\
\text { Bacterial Vaginosis }[34,35] \\
\text { periodontal disease }[36] \\
\text { diarrhoea }[13] \\
\text { periodontal, tonsillitis, peritonsillar abscess, etc }[37] \\
\text { periodontal disease }[38] \\
\text { new genus }[39]\end{array}$ \\
\hline Gut & $\begin{array}{c}104097 \\
8612 \\
6383 \\
3888 \\
3307 \\
2968 \\
1365 \\
787 \\
593 \\
545 \\
414 \\
317 \\
313 \\
310 \\
286\end{array}$ & $\begin{array}{c}\text { Enterococcus } \\
\text { Escherichia } \\
\text { Corynebacterium } \\
\text { Klebsiella } \\
\text { Salmonella } \\
\text { Shigella } \\
\text { Dolosigranulum } \\
\text { Staphylococcus } \\
\text { Carnobacterium } \\
\text { Bacillus } \\
\text { Lactobacillus } \\
\text { Streptococcus } \\
\text { Aerococcus } \\
\text { Erwinia } \\
\text { Sphingomonas }\end{array}$ & $\begin{array}{c}\text { FAC-ANE } \\
\text { FAC-ANE } \\
\text { aerobic } \\
\text { FACANE } \\
\text { FAC-ANE } \\
\text { FAC-ANE } \\
\text { FAC-ANE } \\
\text { FAC-ANE } \\
\text { anaerobic } \\
\text { FAC-ANE } \\
\text { FACANE } \\
\text { FAC-ANE } \\
\text { aerobic } \\
\text { FAC-ANE } \\
\text { aerobic }\end{array}$ & $\begin{array}{c}\text { urinary tract infections; intraabdominal [40] } \\
\text { cholecystitis, bacteremia, cholangitis, urinary tract infection [41] } \\
\text { diphtheria toxin [42] } \\
\text { pneumoni [43] and intestinal colonization [44] } \\
\text { typhoid [45] } \\
\text { eading cause of diarrhoeal death among children [46] } \\
\text { multiple sclerosis [47] } \\
\text { Boils, impetigo, food poisoning, cellulitis, and toxic shock syndrome } \\
\text { frequently isolated from natural environments and foods [48] } \\
\text { Inhalation or respiratory anthrax } \\
\text { mutualistic beneficial relationship with the human body, [49] } \\
\text { pneumonia, bacteremia [29] } \\
\text { Urinary tract infection [50] } \\
\text { dermohypodermitis and bactaeremia [51] }\end{array}$ \\
\hline
\end{tabular}




\section{Healthy control samples}

Controls using healthy samples from BALF and nasopharyngeal does not show homeostasis disruption (Table 10).

The first study (Accid:PRJNA431097) looks at children respiratory tract metagenome (BALF), while the second study (Accid:PRJNA508588) was on nasopharyngeal from children, young adults and seniors. The anaerobes implicated in Covid19 patients are almost absent here - I have highlighted Prevotella. These healthy studies are using 16S rRNA sequencing, while all Covid19 studies are not (ie they sequence everything). But rRNA is the most predominant RNA - and the correlation should hold quite well.

Another good control are the patients themselves - not all patients have anaerobes disrupting homeostasis, and that is a function of the state of the disease. Also, there will be exceptions when another pathogenic bacteria will colonize. For example, in Table 5, Pseudomonas is dominating in one patient. But, even in those five patients, one can see Prevotella more than in healthy controls - leaving aside patients where anaerobes have completely taken over.

In 2013, suggested a 'common link between microaspiration of Prevotella/Veillonella and inflammation' [53]. In 2015, a study about the analysis of the upper respiratory tract microbiotas in healthy individuals suggested that 'subclinical lung inflammation may create an environment that promotes retention of Prevotella in the lungs' or 'Prevotella may stimulate subclinical lung inflammation' [54].

\section{Highly expressed mRNA in deceased 74 yr old Covid19 lung sample clearly shows bacterial infection}

The sequencing data submitted by Mount Sinai (Accid:SRR11517739) shows high expression of several bacterial markers (Table 11). IFITM2- Interferon-induced transmembrane protein have viral roles, but also play a role "in restriction of M. tuberculosis infection" [55]. Another study found 'differences in the representation of the genus Prevotella within the Prevotellaceae family, showing significant increase in abundance' in IFITM3-deficient and knockout mice [56]. Ferritin is also high, it is a well-known marker - "lung pathogens such as $\mathrm{H}$. influenza have developed strategies to acquire iron by using iron-containing human proteins such as tranferrin, lactoferrin, haemoglobin and ferritin" [57]. Also, S100 calcium binding proteins (several figure in the list), along with Procalcitonin (and CRP) which are elevated in many Covid19 patients, are used as marker for bacterial infections [58] A paper was recently published using this (and more data), which reported low Type I and III interferons and elevated chemokines, and thus "reduced innate antiviral defenses". However, they have not reported these bacterial infection markers.

\section{Materials and methods}

All sequencing data analyzed here are in NCBI. Several local programs (using C\# and Perl) were used. Results were corroborated with 'Metaphlan2' a tool for enhanced metagenomic taxonomic profiling [59], and also the NCBI reported results available online.

\section{Discussion}

In the 1918 Spanish flu, where secondary infections was the primary cause of mortality [8], doctors did not have the option of administering antibiotics (discovered in 1928). Secondary infections was also implicated in deaths and hospitalizations in SARS 2003 [9].

In 2020, with a plethora of technical advancements at our disposal, it is unwise to limit ourselves to testing a limited set (18-20) of pathogens in Covid19 patients to rule out secondary infections [6]. Culturing is definitely not a good technique, as was done in Seattle, where mortality was very high [60], since many pathogens are difficult to culture. 
While, it not technically or economically feasible to deploy NGS testing on a large set of patients, NGS data will help tremendously in throwing light on the mechanisms of the disease - specifically, if the disease is the result of synergy between SARS-Cov2 and a hitherto unknown set of opportunistic pathogens.

Here, I present metagenomic studies of Covid19 patient sequencing data from different countries (China, Brazil, Peru, Cambodia, US, etc.). A distinct pattern that emerges from this data is the abundance of anaerobic bacteria (eg Prevotella, Veillonella, Capnocytophaga, Fusobacterium, Oribacterium and Bacteroides) in comparison to aerobic bacteria. This indicates that SARS-Cov2 is enabling these anaerobes to colonize the lungs, disrupting the homeostasis found in healthy patients. The technique used to extract the sample is important as 'acellular BAL contained decreased relative abundance of Prevotella' [61].

These bacteria are known to lower lymphocyte counts [62], increase IL-6 in plasma [12,63,64], cause ground glass opacity in lungs [65], and associated with cardiac injury [66] - all symptoms associated with Covid19. Many studies also show several bacterial infection markers - like D-dimers, C-reactive protein and ferritin - being significantly high (somehow, Procalcitonin is not high, suggesting the calcium signalling is not effected). Although while discussing factors associated with hospitalization and critical illness in 4103 patients with COVID19 disease in New York City, it was noted "many patients with elevated Procalcitonin and critical illness were treated with antibiotics", they were unsure "whether these patients actually had bacterial disease' [5]. Similarly, acute kidney injury in patients hospitalized with COVID-19 in Wuhan had 'higher levels of white blood cells, D-dimer, aspartate aminotransferase, total bilirubin, creatine kinase, lactate dehydrogenase, procalcitonin, C-reactive protein, a higher prevalence of hyperkalemia, lower lymphocyte counts, and higher chest computed tomographic scores' [67].

As mentioned, bacterial infection markers (CRP, D-dimer, LDH, ferritin) are all usually high, while viral immune response is attenuated. This is also confirmed here in the lung sample from a 74 year old deceased patient, showing high levels of IFITM3, ferritin and S100 calcium binding protein. The study which submitted the above data reported that the immune response to viral infection is attenuated - 'low levels of Type I and III interferons juxtaposed to elevated chemokines and high expression of IL- 6' [68]. Another study using ultra-high-throughput proteomics found CD14 and LBP (lipopolysaccharide binding protein) which recognizes bacterial LPS to be upregulated, but ascribed it to immune response dysregulation, rather than bacterial infection [69]. Another paper analyzed blood parameters patients with severe COVID1 and concluded that the parameters resemble a bacterial rather than viral infection [70]. A third paper reported the same when compared to Influenza - 'profound suppression in type I and type II interferon signaling in COVID-19 patients across multiple clusters' [71]. Finally, doctors from a Bangkok hospital found that "bacterial DNA and toxins were discovered in virtual all severely ill COVID-19 pneumonia patients" $(\mathrm{N}=19)$ [72]. The endotoxin (EAA) test used above is specific for the lipid portion of endotoxin (LPS). In 19 patients, EAA was high in $8(¿ 0.6)$ and intermediate $(0.4-0.6)$ in 11. And, 18/19 patients were +ve for $16 \mathrm{~S}$ rRNA gene amplification - although only 1 blood culture was +ve.

In the Spanish flu, many patients developed a 'post influenza pneumonia a few days after the onset of the influenza symptoms', which occurred without 'any new alarming symptoms and a prolonged duration of elevated temperature was commonly the first indication of a secondary infection' [8]. This "secondary worsening around 10 days after disease onset despite a decreasing viral load" is also being noticed in Covid19 [73]. The inability to find any viral load in severely sick patients also indicate a secondary reason for the disease [74]. Also, the analysis of 92 deceased patients in Wuhan revealed septic shock (7.6\%) to be the second most common reason for mortality after ARDS (79.3\%) [75]. Furthermore, among 54 non-survivors out of 191 patients, 27 (50\%) had secondary infections, and 38\% died of septic shock [4].

Blood (and urine) do not usually yield virus in Covid19. For example "none of 27 urine samples and none of 31 serum samples were tested positive for SARS-CoV2 RNA" [76], virus was not detected in 10 urine samples [77], only 4 urine samples were positive for viral nucleic acid out of 58 cases [78]. Finally, deep sequencing of 3 samples did not yield any virus [79]. Thus, the theory that the virus attacks hemoglobin chain does not appear to be true [80].

While the trigger of such an event is still elusive, once this happens, many features of the disease could be explained by the fact that these bacteria express hemoglobin degrading proteins [81], heme-binding proteins sequestering heme after hemoglobin degradation [82], "plundering" iron, and thereby sequestering oxygen [83]. 
Hypoxia could also result from formate, the by-product of anaerobic respiration, which inhibits mitochondrial cytochrome oxidase, causing hypoxia at the cellular level [84].

Studies often ignore possible pathogens as nontoxigenic. For example, aerobic/anaerobic cultures of the lung tissue grew 'nontoxigenic Escherichia coli, Candida tropicalis, and Proteus mirabilis.' in the autopsy results of a 42-year-old obese man with muscular dystrophy, where nasopharyngeal swabs were positive and the lung parenchymal swabs were negative for SARS-Cov2 [85]. They did not find viral inclusions, while the lungs had foci of acute bronchopneumonia. Finally, there was liver cirrhosis, renal nephrosclerosis and tubular fan-shaped crystals in the kidneys. The cause of death was listed as "complications of hepatic cirrhosis" [85]. However, the facultatively anaerobic Proteus mirabilis is implicated in several of the reasons responsible for the death of the patient. Urease is an important virulence factor for Proteus mirabilis. It hydrolyzes urea, leading to stone formation [86]. Within the stones, 'COM crystals are arranged radially into fan-shaped profiles with distinct concentric laminations' [87] (see autopsy results). Proteus mirabilis has unique kidney pathology, and is an unique species that causes a large number of kidney stone formation, and greater kidney damage in rats than other similar bacteria with urease enzymes [88]. Patients with cirrhosis have a higher proportion of Proteus species compared with control,their presence in the gut are known to contribute to the pathogenesis of hepatic encephalopathy by breaking down urea into ammonia and carbonic acid [89] While, Proteus mirabilis is not associated with pneumonia very often, 13 patients with Proteus mirabilis pneumonia in Japan showed resistance for levofloxacin [90], while extended-spectrum $\beta$-Lactamase producing Proteus mirabilis was implicated in pneumonia in Korea [91]. The detection of Proteus mirabilis should have been considered more seriously as a causative agent of mortality since it is implicated in all of the reported maladies, especially in the kidneys.

Should this secondary infection by anaerobes prove to be a common occurrence in Covid19 patients, anaerobe-specific antibiotics, like doxycycline/Metronidazole, should be in the treatment regimen to supplement Azithromycin being used currently [7] since some anaerobic bacteria have resistance for Azithromycin [92].

Another intriguing question being asked is - does the BCG vaccine provide immunity against SARSCov2 [93]? There might be another angle to this hypothesis - does Mycobacterium tuberculosis (MTB) really do the same, since BCG is used in MTB endemic countries? A recent study note that 'MTB+ patients were enriched with Anoxybacillus,while MTB- patients were enriched with Prevotella, Alloprevotella, Veillonella, and Gemella' [94]. This observation is reiterated in another study - 'yet in pulmonary tuberculosis, contrary to expectation, Prevotella species are decreased rather than increased' [95], which goes ahead to propose a mechanism to this resistance - MTB exopolyphosphatase. In short, maybe MTB does not allow anaerobic bacteria to break the homeostasis in their favor.

SARS-2003 showed a lot of similar symptoms, which did not get enough media attention. There was a specific warning issued in 2004 for 'an increased vigilance against stroke and other thrombotic complications among critically-ill SARS patients in future outbreaks' [96]. A study including 64 male and 93 female patients showed thrombocytosis in $77(49 \%)$, haemoglobin count in $95(61 \%)$ and lymphopenia in $153(98 \%)$ patients [97]. Similarly, another study noted that several organs were affected by the virus [98]. Finally, fibrinoid necrosis in the walls of small blood vessels in 'lungs, heart, liver, kidneys, adrenal glands, brain, gastrointestinal tract, and muscle tissues' confirmed widespread thrombosis associated with SARS [99].

Finally, anaerobic bacteria causing initial symptoms like persistent fever, chills, pain and later symptoms like ARDS, blood clots and septic shock finds resonance in a "forgotten disease" - Lemierre syndrome (LS) - "characterized by an acute oropharyngeal infection, suppurative thrombophlebitis of the internal jugular vein, anaerobic sepsis, and metastatic infections' [100]. While, the most common offending pathogen in LS is the anaerobic Fusobacterium necrophorum, Prevotella was implicated in the case of a previously healthy 15-year-old admitted to the ICU because of septic shock, brain, arterial stroke and lung abscesses, and a positive blood culture for Prevotella oris [101]. In another example, a healthy immunocompetent 23-year-old male had symptoms of general malaise, difficulty in breathing, fever, and chest pain, and 'Ultrasound and $\mathrm{CT}$ imaging revealed internal jugular vein thrombosis with associated septic emboli reaching the lungs to form bilateral cavitations and consequently pleural effusions' [102]. Another connection to Covd19 reports the arterial stroke [103] and severe narrowing of the left cavernous carotid artery [104]. Lately, it is been reported that Covid19 is more of a vascular problem (DIC - disseminated intravascular coagulation), than 
one of the lungs [105-109]. Also, antiphospholipid syndrome (APS), which leads to ARDS, could be another common feature in both these diseases [110]. It is to be noted Covid19 symptoms (mostly) does not emanate from the jugular vein, but from the lungs (though both have an oral angle, making hygiene an important consideration [111]). And the sequencing data also suggests anaerobic colonization in that region.

Just as I have postulated above that SARS-Cov2 enables anaerobes, viral infections by acute Epstein Barr Virus (EBV) can create 'conditions conducive to anaerobic growth, like a peritonsillar abscess, allow growth and penetration of the surrounding tissues by F. necrophorum' [112]. There are several such instances of Lemierre's Syndrome following EBV infection [113,114]. The interaction between Lemierre's syndrome and EBV 'is complex and can cause diagnostic uncertainty, particularly in early infection' [115].

EBV infection that precedes and predisposes patients to Lemierre's happens possibly 'by a transient depression of $\mathrm{T}$ cell immunity. and 'fusobacterium can cause false positive results in EBV rapid tests and in mycoplasma pneumoniae PCR' [115]. Type III IFN (IFN- $\lambda$ ) are a recent discovery [116], shown to decrease 'neutrophil motility and function in the influenza-infected lung, which increases the bacterial burden during superinfection' [117]. Recent work shows that IFN- $\lambda$ may promote bacterial superinfection in Covid19 [118,119]. Finally, co-infection with EBV and SARS-Cov2 was associated with fever, increased inflammation and higher CRP (bacterial marker) [120]. On that note, I leave this correlation of Covid19 to Lemierre syndrome.

\section{Competing interests}

No competing interests were disclosed.

\section{References}

1. Zhu N, Zhang D, Wang W, Li X, Yang B, et al. (2020) A novel coronavirus from patients with pneumonia in China, 2019. New England Journal of Medicine .

2. Velavan TP, Meyer CG (2020) The COVID-19 epidemic. Trop Med Int Health 25: 278-280.

3. Hu K, Zhao Y, Wang M, Zeng Q, Wang X, et al. (2020) Identification of a super-spreading chain of transmission associated with COVID-19. medRxiv .

4. Zhou F, Yu T, Du R, Fan G, Liu Y, et al. (2020) Clinical course and risk factors for mortality of adult inpatients with COVID-19 in Wuhan, China: a eetrospective cohort study. The Lancet .

5. Petrilli CM, Jones SA, Yang J, Rajagopalan H, O'Donnell LF, et al. (2020) Factors associated with hospitalization and critical illness among 4,103 patients with covid-19 disease in new york city. medRxiv .

6. Richardson S, Hirsch JS, Narasimhan M, Crawford JM, McGinn T, et al. Presenting characteristics, comorbidities, and outcomes among 5700 patients hospitalized with covid-19 in the new york city area. JAMA .

7. Gautret P, Lagier JC, Parola P, Meddeb L, Mailhe M, et al. (2020) Hydroxychloroquine and azithromycin as a treatment of COVID-19: results of an open-label non-randomized clinical trial. International Journal of Antimicrobial Agents : 105949.

8. Holtenius J, Gillman A (2014) The spanish flu in uppsala, clinical and epidemiological impact of the influenza pandemic 1918-1919 on a swedish county. Infection ecology \& epidemiology 4: 21528.

9. Jiang Y, Xu J, Zhou C, Wu Z, Zhong S, et al. (2005) Characterization of cytokine/chemokine profiles of severe acute respiratory syndrome. American journal of respiratory and critical care medicine 171: 850-857. 
10. Wu F, Zhao S, Yu B, Chen Y, Wang W, et al. (2020) Complete genome characterisation of a novel coronavirus associated with severe human respiratory disease in Wuhan. China bioRxiv 24.

11. Sarkar S, Hallström T, Hammerschmidt S, Skerka C, Zipfel P (2013) Elongation factor tu (tuf) is a new virulence factor of streptococcus pneumoniae that binds human complement factors, aids in immune evasion and host tissue invasion. Molecular Immunology 3: 312.

12. Larsen JM (2017) The immune response to Prevotella bacteria in chronic inflammatory disease. Immunology 151: 363-374.

13. Lindblom GB, Sjögren E, Hansson-Westerberg J, Kaijser B (1995) Campylobacter upsaliensis, C. sputorum sputorum and C. concisus as common causes of diarrhoea in Swedish children. Scandinavian journal of infectious diseases 27: 187-188.

14. Nelson JM, Smith KE, Vugia DJ, Rabatsky-Ehr T, Segler SD, et al. (2004) Prolonged diarrhea due to ciprofloxacin-resistant Campylobacter infection. The Journal of infectious diseases 190: 1150-1157.

15. Chen L, Liu W, Zhang Q, Xu K, Ye G, et al. (2020) RNA based mNGS approach identifies a novel human coronavirus from two individual pneumonia cases in 2019 Wuhan outbreak. Emerging Microbes \& Infections 9: 313-319.

16. Downes J, Dewhirst FE, Tanner AC, Wade WG (2013) Description of Alloprevotella rava gen. nov., sp. nov., isolated from the human oral cavity, and reclassification of Prevotella tannerae moore et al. 1994 as alloprevotella tannerae gen. nov., comb. nov. International journal of systematic and evolutionary microbiology 63: 1214 .

17. Ahmed B, Cox MJ, Cuthbertson L, James PL, Cookson WO, et al. (2018) Comparison of the upper and lower airway microbiota in children with chronic lung diseases. PloS one 13.

18. Perlman S (2020). Another decade, another coronavirus.

19. Favila Menezes M, Sousa MJ, Paixão P, Atouguia J, Negreiros I, et al. (2018) Lawsonella clevelandensis as the causative agent of a breast abscess .

20. Zamora JAG, Alvarez MR, Henry Z, Baracco GJ, Dickinson G, et al. (2020) Liver abscess caused by lawsonella clevelandensis in a patient with rheumatoid arthritis: A case report and literature review. IDCases : e00734.

21. Kumaria A, Lucas E, Crusz S, Howarth S, Cartmill M (2018) Lawsonella clevelandensis causing spinal subdural empyema. British journal of neurosurgery : 1-3.

22. Jovita MR, Collins MD, Sjödén B, Falsen E (1999) Characterization of a novel atopobium isolate from the human vagina: description of atopobium vaginae sp. nov. International Journal of Systematic and Evolutionary Microbiology 49: 1573-1576.

23. Mendling W, Palmeira-de Oliveira A, Biber S, Prasauskas V (2019) An update on the role of atopobium vaginae in bacterial vaginosis: what to consider when choosing a treatment? a mini review. Archives of gynecology and obstetrics : 1-6.

24. Polatti F (2012) Bacterial vaginosis, atopobium vaginae and nifuratel. Current clinical pharmacology 7: $36-40$.

25. Chen L, Wen Ym (2011) The role of bacterial biofilm in persistent infections and control strategies. International journal of oral science 3: 66-73. 
26. Alves P, Castro J, Sousa C, Cereija TB, Cerca N (2014) Gardnerella vaginalis outcompetes 29 other bacterial species isolated from patients with bacterial vaginosis, using in an in vitro biofilm formation model. The Journal of infectious diseases 210: 593-596.

27. Bhatti MA, Frank MO (2000) Veillonella parvula meningitis: case report and review of veillonella infections. Clinical infectious diseases 31: 839-840.

28. Nagaoka K, Yanagihara K, Morinaga Y, Nakamura S, Harada T, et al. (2014) Prevotella intermedia induces severe bacteremic pneumococcal pneumonia in mice with upregulated platelet-activating factor receptor expression. Infection and immunity 82: 587-593.

29. Cunningham MW (2000) Pathogenesis of group a streptococcal infections. Clinical microbiology reviews 13: 470-511.

30. Li J, Li Y, Zhou Y, Wang C, Wu B, et al. (2018) Actinomyces and alimentary tract diseases: A review of its biological functions and pathology. BioMed research international 2018.

31. Matias WR, Bourque DL, Niwano T, Onderdonk AB, Katz JT (2016) Subacute bacterial endocarditis with Leptotrichia goodfellowii in a patient with a valvular allograft: a case report and review of the literature. Case reports in infectious diseases 2016.

32. Goldstein EJ, Murphy TF, Parameswaran GI (2009) Moraxella catarrhalis, a human respiratory tract pathogen. Clinical Infectious Diseases 49: 124-131.

33. Wexler HM (2007) Bacteroides: the good, the bad, and the nitty-gritty. Clinical microbiology reviews 20: $593-621$.

34. Marrazzo JM, Fiedler TL, Srinivasan S, Thomas KK, Liu C, et al. (2012) Extravaginal reservoirs of vaginal bacteria as risk factors for incident bacterial vaginosis. The Journal of infectious diseases 205: $1580-1588$.

35. Lanjekar V, Marathe N, Ramana VV, Shouche Y, Ranade D (2014) Megasphaera indica sp. nov., an obligate anaerobic bacteria isolated from human faeces. International journal of systematic and evolutionary microbiology 64: 2250-2256.

36. Diaz PI, Slakeski N, Reynolds EC, Morona R, Rogers AH, et al. (2006) Role of oxyr in the oral anaerobe Porphyromonas gingivalis. Journal of bacteriology 188: 2454-2462.

37. Han YW (2015) Fusobacterium nucleatum: a commensal-turned pathogen. Current opinion in microbiology 23: 141-147.

38. Gonçalves LF, Fermiano D, Feres M, Figueiredo LC, Teles FR, et al. (2012) Levels of Selenomonas species in generalized aggressive periodontitis. Journal of periodontal research 47: 711-718.

39. Hedberg ME, Moore ER, Svensson-Stadler L, Hörstedt P, Baranov V, et al. (2012) Lachnoanaerobaculum gen. nov., a new genus in the lachnospiraceae: characterization of lachnoanaerobaculum umeaense gen. nov., sp. nov., isolated from the human small intestine, and lachnoanaerobaculum orale sp. nov., isolated from saliva, and reclassification of eubacterium saburreum (prévot 1966) holdeman and moore 1970 as lachnoanaerobaculum saburreum comb. nov. International journal of systematic and evolutionary microbiology 62: 2685.

40. Murray BE (1990) The life and times of the enterococcus. Clinical microbiology reviews 3: 46-65.

41. DuPont HL, Formal SB, Hornick RB, Snyder MJ, Libonati JP, et al. (1971) Pathogenesis of escherichia coli diarrhea. New England Journal of Medicine 285: 1-9. 
42. Murphy JR (1996) Corynebacterium diphtheriae. In: Medical Microbiology. 4th edition, University of Texas Medical Branch at Galveston.

43. Diancourt L, Passet V, Verhoef J, Grimont PA, Brisse S (2005) Multilocus sequence typing of klebsiella pneumoniae nosocomial isolates. Journal of clinical microbiology 43: 4178-4182.

44. SELDEN R, Lee S, Wang WLL, BENNETT JV, EICKHOFF TC (1971) Nosocomial klebsiella infections: intestinal colonization as a reservoir. Annals of Internal Medicine 74: 657-664.

45. Gal-Mor O, Boyle EC, Grassl GA (2014) Same species, different diseases: how and why typhoidal and non-typhoidal salmonella enterica serovars differ. Frontiers in microbiology 5: 391.

46. Tickell KD, Brander RL, Atlas HE, Pernica JM, Walson JL, et al. (2017) Identification and management of shigella infection in children with diarrhoea: a systematic review and meta-analysis. The Lancet Global Health 5: e1235-e1248.

47. Jorge FM (2014) The potential pathogenicity of Dolosigranulum pigrum in multiple sclerosis, and the occurrence of the organism in the upper respiratory tract .

48. Leisner JJ, Laursen BG, Prévost H, Drider D, Dalgaard P (2007) Carnobacterium: positive and negative effects in the environment and in foods. FEMS microbiology reviews 31: 592-613.

49. Sherid M, Samo S, Sulaiman S, Husein H, Sifuentes H, et al. (2016) Liver abscess and bacteremia caused by lactobacillus: role of probiotics? case report and review of the literature. BMC gastroenterology 16: 138.

50. Rasmussen M (2016) Aerococcus: an increasingly acknowledged human pathogen. Clinical Microbiology and Infection 22: 22-27.

51. Prod'homme M, Micol L, Weitsch S, Gassend JL, Martinet O, et al. (2017) Cutaneous infection and bactaeremia caused by erwinia billingiae: a case report. New microbes and new infections 19: $134-136$.

52. Bayram N, Devrim I, Apa H, Gulfidan G, Turkyilmaz HN, et al. (2013) Sphingomonas paucimobilis infections in children: 24 case reports. Mediterranean journal of hematology and infectious diseases 5.

53. Segal LN, Alekseyenko AV, Clemente JC, Kulkarni R, Wu B, et al. (2013) Enrichment of lung microbiome with supraglottic taxa is associated with increased pulmonary inflammation. Microbiome 1: 19 .

54. Bassis CM, Erb-Downward JR, Dickson RP, Freeman CM, Schmidt TM, et al. (2015) Analysis of the upper respiratory tract microbiotas as the source of the lung and gastric microbiotas in healthy individuals. MBio 6: e00037-15.

55. Ranjbar S, Haridas V, Jasenosky LD, Falvo JV, Goldfeld AE (2015) A role for ifitm proteins in restriction of mycobacterium tuberculosis infection. Cell reports 13: 874-883.

56. Alteber Z, Sharbi-Yunger A, Pevsner-Fischer M, Blat D, Roitman L, et al. (2018) The antiinflammatory ifitm genes ameliorate colitis and partially protect from tumorigenesis by changing immunity and microbiota. Immunology and cell biology 96: 284-297.

57. Khiroya H, Turner AM (2015) The role of iron in pulmonary pathology. Multidisciplinary respiratory medicine 10: 34 . 
58. Kim HA, Jeon JY, An JM, Koh BR, Suh CH (2012) C-reactive protein is a more sensitive and specific marker for diagnosing bacterial infections in systemic lupus erythematosus compared to s100a8/a9 and procalcitonin. The Journal of rheumatology 39: 728-734.

59. Truong DT, Franzosa EA, Tickle TL, Scholz M, Weingart G, et al. (2015) Metaphlan2 for enhanced metagenomic taxonomic profiling. Nature methods 12: 902-903.

60. Bhatraju PK, Ghassemieh BJ, Nichols M, Kim R, Jerome KR, et al. (2020) Covid-19 in critically ill patients in the Seattle region - case series. New England Journal of Medicine .

61. Dickson RP, Erb-Downward JR, Prescott HC, Martinez FJ, Curtis JL, et al. (2014) Cell-associated bacteria in the human lung microbiome. Microbiome 2: 28.

62. Shenker B, Vitale L, Slots J (1991) Immunosuppressive effects of Prevotella intermedia on in vitro human lymphocyte activation. Infection and immunity 59: 4583-4589.

63. Leite AZ, Rodrigues NdC, Gonzaga MI, Paiolo JCC, de Souza CA, et al. (2017) Detection of increased plasma interleukin-6 levels and prevalence of Prevotella copri and Bacteroides vulgatus in the feces of type 2 diabetes patients. Frontiers in immunology 8: 1107.

64. Choi EY, Jin JY, Choi JI, Choi IS, Kim SJ (2014) Effect of azithromycin on Prevotella intermedia lipopolysaccharide-induced production of interleukin-6 in murine macrophages. European journal of pharmacology 729: 10-16.

65. Berardino ADM, Inchingolo R, Smargiassi A, Re A, Torelli R, et al. (2014) Empyema caused by Prevotella bivia complicating an unusual case of spontaneous chylothorax. Journal of clinical microbiology 52: 1284-1286.

66. Dorn BR, Dunn WA, Progulske-Fox A (1999) Invasion of human coronary artery cells by periodontal pathogens. Infection and immunity 67: 5792-5798.

67. Xiao G, Hu H, Wu F, Sha T, Huang Q, et al. (2020) Acute kidney injury in patients hospitalized with covid-19 in wuhan, china: A single-center retrospective observational study. medRxiv .

68. Blanco-Melo D, Nilsson-Payant BE, Liu WC, Uhl S, Hoagland D, et al. (2020) Imbalanced host response to sars-cov-2 drives development of covid-19. Cell .

69. Messner CB, Demichev V, Wendisch D, Michalick L, White M, et al. (2020) Clinical classifiers of covid-19 infection from novel ultra-high-throughput proteomics. medRxiv .

70. Kukar M, Gunčar G, Vovko T, Podnar S, Černelč P, et al. (2020) Covid-19 diagnosis by routine blood tests using machine learning. arXiv preprint arXiv:200603476 .

71. Mudd PA, Crawford JC, Turner JS, Souquette A, Reynolds D, et al. (2020) Targeted immunosuppression distinguishes covid-19 from influenza in moderate and severe disease. medRxiv .

72. Sirivongrangson P, Kulvichit W, Payungporn S, Pisitkun T, Chindamporn A, et al. (2020) Endotoxemia and circulating bacteriome in severe covid-19 patients. medRxiv .

73. Lescure FX, Bouadma L, Nguyen D, Parisey M, Wicky PH, et al. (2020) Clinical and virological data of the first cases of covid-19 in europe: a case series. The Lancet Infectious Diseases .

74. Jiang G, Ren X, Liu Y, Chen H, Liu W, et al. (2020) Application and optimization of RT-PCR in diagnosis of SARS-CoV-2 infection. medRxiv .

75. Yang F, Shi S, Zhu J, Shi J, Dai K, et al. (2020) Analysis of 92 deceased patients with covid-19. Journal of Medical Virology . 
76. Wölfel R, Corman VM, Guggemos W, Seilmaier M, Zange S, et al. (2020) Virological assessment of hospitalized patients with covid-2019. Nature : 1-10.

77. Young BE, Ong SWX, Kalimuddin S, Low JG, Tan SY, et al. (2020) Epidemiologic features and clinical course of patients infected with sars-cov-2 in singapore. Jama .

78. Ling Y, Xu SB, Lin YX, Tian D, Zhu ZQ, et al. (2020) Persistence and clearance of viral rna in 2019 novel coronavirus disease rehabilitation patients. Chinese medical journal .

79. Xiong Y, Liu Y, Cao L, Wang D, Guo M, et al. (2020) Transcriptomic characteristics of bronchoalveolar lavage fluid and peripheral blood mononuclear cells in COVID-19 patients. Available at SSRN 3549993 .

80. Wenzhong L, Hualan L Covid-19: Attacks the 1-beta chain of hemoglobin and captures the porphyrin to inhibit human heme metabolism. chemrxiv. 2020. Preprint https://doi org/1026434/chemrxiv 11938173: v6.

81. Guan SM, Nagata H, Shizukuishi S, Wu JZ (2006) Degradation of human hemoglobin by Prevotella intermedia. Anaerobe 12: 279-282.

82. Tong Y, Guo M (2009) Bacterial heme-transport proteins and their heme-coordination modes. Archives of biochemistry and biophysics 481: 1-15.

83. Ndongo S, Khelaifia S, Lagier JC, Raoult D (2019) From anaerobes to aerointolerant prokaryotes. Human Microbiome Journal : 100068.

84. Takahashi N, Yamada T (2000) Glucose metabolism by prevotella intermedia and prevotella nigrescens. Oral microbiology and immunology 15: 188-195.

85. Barton LM, Duval EJ, Stroberg E, Ghosh S, Mukhopadhyay S (2020) Covid-19 autopsies, oklahoma, usa. American Journal of Clinical Pathology .

86. Jones B, Mobley H (1988) Proteus mirabilis urease: genetic organization, regulation, and expression of structural genes. Journal of bacteriology 170: 3342-3349.

87. Khan SR, Pearle MS, Robertson WG, Gambaro G, Canales BK, et al. (2016) Kidney stones. Nature Reviews Disease Primers 2: 1-23.

88. Armbruster CE, Mobley HL, Pearson MM (2018) Pathogenesis of proteus mirabilis infection. EcoSal Plus 8.

89. Hamilton AL, Kamm MA, Ng SC, Morrison M (2018) Proteus spp. as putative gastrointestinal pathogens. Clinical microbiology reviews 31: e00085-17.

90. Okimoto N, Hayashi T, Ishiga M, Nanba F, Kishimoto M, et al. (2010) Clinical features of proteus mirabilis pneumonia. Journal of infection and chemotherapy 16: 364-366.

91. Ryou SH, Bae JW, Baek HJ, Lee DH, Lee SW, et al. (2015) Pulmonary pneumatocele in a pneumonia patient infected with extended-spectrum $\beta$-lactamase producing proteus mirabilis. Tuberculosis and respiratory diseases 78 : $371-374$.

92. Arredondo A, Blanc V, Mor C, Nart J, León R (2019) Azithromycin and erythromycin susceptibility and macrolide resistance genes in Prevotella from patients with periodontal disease. Oral diseases 25: $860-867$.

93. Kurthkoti K, Das G (2020) Mechanism of heterologous resistance of bcg to covid-19 . 
94. Hu Y, Kang Y, Liu X, Cheng M, Dong J, et al. (2020) Distinct lung microbial community states in patients with pulmonary tuberculosis. Science China Life Sciences .

95. Block J (2019) Exopolyphosphatase of mycobacterium tuberculosis might limit the growth of bacteria which thrive in inflamed and injured lung. Arch Microbiol 3: 102-106.

96. Umapathi T, Kor AC, Venketasubramanian N, Lim CT, Pang BC, et al. (2004) Large artery ischaemic stroke in severe acute respiratory syndrome (sars). Journal of neurology 251: 1227-1231.

97. Wong RS, Wu A, To K, Lee N, Lam CW, et al. (2003) Haematological manifestations in patients with severe acute respiratory syndrome: retrospective analysis. Bmj 326: 1358-1362.

98. Gu J, Gong E, Zhang B, Zheng J, Gao Z, et al. (2005) Multiple organ infection and the pathogenesis of sars. The Journal of experimental medicine 202: 415-424.

99. Xiang-hua Y, Le-min W, Ai-bin L, Zhu G, Riquan L, et al. (2010) Severe acute respiratory syndrome and venous thromboembolism in multiple organs. American journal of respiratory and critical care medicine 182: 436-437.

100. Weesner CL, Cisek JE (1993) Lemierre syndrome: the forgotten disease. Annals of emergency medicine 22: $256-258$.

101. Garza-Alatorre A, Hernández-Rosales C, Rodríguez-Coronado J, Solís-González MC, BalderramaDávila R, et al. (2015) Atypical lemierre's syndrome caused by prevotella oris. Medicina universitaria 17: $218-221$.

102. Hadjinicolaou AV, Philippou Y (2015) Lemierre's syndrome: a neglected disease with classical features. Case reports in medicine 2015.

103. Bentham JR, Pollard AJ, Milford CA, Anslow P, Pike MG (2004) Cerebral infarct and meningitis secondary to lemierre's syndrome. Pediatric neurology 30: 281-283.

104. DeGaffe GH, Murphy JR, Butler IJ, Shelburne J, Heresi GP (2013) Severe narrowing of left cavernous carotid artery associated with fusobacterium necrophorum infection. Anaerobe 22: 118-120.

105. Tang N, Li D, Wang X, Sun Z (2020) Abnormal coagulation parameters are associated with poor prognosis in patients with novel coronavirus pneumonia. Journal of Thrombosis and Haemostasis .

106. Cui S, Chen S, Li X, Liu S, Wang F (2020) Prevalence of venous thromboembolism in patients with severe novel coronavirus pneumonia. Journal of Thrombosis and Haemostasis .

107. Kollias A, Kyriakoulis KG, Dimakakos E, Poulakou G, Stergiou GS, et al. (2020) Thromboembolic risk and anticoagulant therapy in covid-19 patients: Emerging evidence and call for action. British Journal of Haematology .

108. Leisman DE, Deutschman CS, Legrand M Facing covid-19 in the icu: vascular dysfunction, thrombosis, and dysregulated inflammation. Intensive Care Medicine : 1.

109. Choi MH, Jung JI, Chung WD, Kim YJ, Lee SE, et al. (2014) Acute pulmonary complications in patients with hematologic malignancies. Radiographics 34: 1755-1768.

110. Cho YP, Choi SJ, Jung BH, Hwang JW, Han MS, et al. (2006) Lemierre's syndrome in a patient with antiphospholipid syndrome. Annals of vascular surgery 20: 274-277.

111. Sampson V (2020) Oral hygiene risk factor. British Dental Journal 228: 569-569.

112. Allen BW, Bentley TP (2019) Lemierre syndrome . 
113. Boz G, Iskender S, Caylan R, Aydin K, Koksal I (2005) A case of lemierre's syndrome following epstein-barr virus infection. Anaerobe 11: 185-187.

114. Chacko E, Krilov L, Patten W, Lee P (2010) Lemierre's and lemierre's-like syndromes in association with infectious mononucleosis. The Journal of Laryngology \& Otology 124: 1257-1262.

115. Rae J, Misselbrook K (2017) Lemierre's syndrome-a rare cause of disseminated sepsis requiring multi-organ support. Journal of the Intensive Care Society 18: 329-333.

116. Kotenko SV, Rivera A, Parker D, Durbin JE (2019) Type iii ifns: Beyond antiviral protection. In: Seminars in immunology. Elsevier, volume 43, p. 101303.

117. Rich HE, McCourt CC, Zheng WQ, McHugh KJ, Robinson KM, et al. (2019) Interferon lambda inhibits bacterial uptake during influenza superinfection. Infection and immunity 87: e00114-19.

118. Broggi A, Ghosh S, Sposito B, Spreafico R, Balzarini F, et al. (2020) Type iii interferons disrupt the lung epithelial barrier upon viral recognition. Science .

119. Major J, Crotta S, Llorian M, McCabe TM, Gad HH, et al. (2020) Type i and iii interferons disrupt lung epithelial repair during recovery from viral infection. Science .

120. Chen T, Song J, Liu H, Zheng H, Chen C (2020) Positive epstein-barr virus detection in corona virus disease 2019 (covid-19) patients. Available at SSRN 3555268 .

121. Chan JFW, Yuan S, Kok KH, To KKW, Chu H, et al. (2020) A familial cluster of pneumonia associated with the 2019 novel coronavirus indicating person-to-person transmission: a study of a family cluster. The Lancet .

122. Rossmann SN, Wilson PH, Hicks J, Carter B, Cron SG, et al. (1998) Isolation of Lautropia mirabilis from oral cavities of human immunodeficiency virus-infected children. Journal of clinical microbiology 36: $1756-1760$.

123. Nieves W, Heang J, Asakrah S, Zu Bentrup KH, Roy CJ, et al. (2010) Immunospecific responses to bacterial elongation factor Tu during Burkholderia infection and immunization. PloS one 5.

124. Chu HW, Honour JM, Rawlinson CA, Harbeck RJ, Martin RJ (2003) Effects of respiratory Mycoplasma pneumoniae infection on allergen-induced bronchial hyperresponsiveness and lung inflammation in mice. Infection and immunity 71: 1520-1526.

125. Weyand NJ (2017) Neisseria models of infection and persistence in the upper respiratory tract. Pathogens and disease 75 .

126. Zhang Z, Deng W, Wang S, Xu L, Yan L, et al. (2017) First case report of infection caused by Cupriavidus gilardii in a non-immunocompromised Chinese patient. IDCases 10: 127-129.

127. Monodane T, Kawabata Y, Takada H (1997) Micrococcus luteus cells and cell walls induce anaphylactoid reactions accompanied by early death and serum cytokines in mice primed with muramyl dipeptide. FEMS Immunology \& Medical Microbiology 17: 49-55.

128. Wenzler E, Kamboj K, Balada-Llasat JM (2015) Severe sepsis secondary to persistent Lysinibacillus sphaericus, Lysinibacillus fusiformis and Paenibacillus amylolyticus bacteremia. International Journal of Infectious Diseases 35: 93-95.

129. Hundertmark M, Williams T, Vogel A, Moritz M, Bramlage P, et al. (2019) Capnocytophaga canimorsus as cause of fatal sepsis. Case reports in infectious diseases 2019. 
130. Chakraborty S (2020). Metagenome of SARS-Cov2 from a patient in Brazil shows a wide range of bacterial species - Lautropia, Prevotella, Haemophilus - overshadowing viral reads, which does not even add up to a full genome, explaining false negatives. doi:10.31219/osf.io/2xt3w. URL osf.io/2xt3w.

131. Wahl B, O’Brien KL, Greenbaum A, Majumder A, Liu L, et al. (2018) Burden of Streptococcus pneumoniae and Haemophilus influenzae type $\mathrm{b}$ disease in children in the era of conjugate vaccines: global, regional, and national estimates for 2000-15. The Lancet Global Health 6: e744-e757.

132. RYCROFT AN, GARSIDE LH (2000) Actinobacillus species and their role in animal disease. The Veterinary Journal 159: 18-36.

133. Long P, Sly L, Pham A, Davis G (1981) Characterization of Morococcus cerebrosus gen. nov., sp. nov. and comparison with Neisseria mucosa. International Journal of Systematic and Evolutionary Microbiology 31: 294-301.

134. Chen Y, Zhang W, Yi H, Wang B, Xiao J, et al. (2020) Microbial community composition and its role in volatile compound formation during the spontaneous fermentation of ice wine made from Vidal grapes. Process Biochemistry .

135. Benga L, Knorr JI, Engelhardt E, Gougoula C, Benten PM, et al. (2019) Current distribution of Rodentibacter species among the mice and rats of an experimental facility. Journal of the American Association for Laboratory Animal Science 58: 475-478.

136. Raja M, Ummer F, Dhivakar C (2014) Aggregatibacter actinomycetemcomitans-a tooth killer? Journal of clinical and diagnostic research: JCDR 8: ZE13.

137. Rafiei M, Kiani F, Sayehmiri F, Sayehmiri K, Sheikhi A, et al. (2017) Study of Porphyromonas gingivalis in periodontal diseases: A systematic review and meta-analysis. Medical journal of the Islamic Republic of Iran 31: 62.

138. Köndgen S, Leider M, Lankester F, Bethe A, Lübke-Becker A, et al. (2011) Pasteurella multocida involved in respiratory disease of wild chimpanzees. PloS one 6.

139. Stroup JS, Bransteitter BA, Reust R (2007) Infective endocarditis caused by Gemella species. Infectious Diseases in Clinical Practice 15: 203-205.

140. Principi N, Esposito S (2015) Kingella kingae infections in children. BMC infectious diseases 15: 260.

141. Kim W (2012) Application of metagenomic techniques: understanding the unrevealed human microbiota and explaining the in clinical infectious diseases. Journal of Bacteriology and Virology 42: 263-275.

142. Bhatti MA, Frank MO (2000) Veillonella parvula meningitis: case report and review of veillonella infections. Clinical infectious diseases 31: 839-840.

143. Afra K, Laupland K, Leal J, Lloyd T, Gregson D (2013) Incidence, risk factors, and outcomes of fusobacterium species bacteremia. BMC infectious diseases 13: 264.

144. Costalonga M, Herzberg MC (2014) The oral microbiome and the immunobiology of periodontal disease and caries. Immunology letters 162: 22-38.

145. Elliott SP (2007) Rat bite fever and Streptobacillus moniliformis. Clinical microbiology reviews 20: $13-22$. 
146. Cincotta MC, Coffey K, Moonah SN, Uppal D, Hughes MA (2015) Case report of Granulicatella adiacens as a cause of bacterascites. Case reports in infectious diseases 2015.

147. Sizova MV, Muller P, Panikov N, Mandalakis M, Hohmann T, et al. (2013) Stomatobaculum longum gen. nov., sp. nov., an obligately anaerobic bacterium from the human oral cavity. International journal of systematic and evolutionary microbiology 63: 1450 .

148. Males B, Berthold P, Dougherty P, Listgarten M (1984) Helical flagellation in Centipeda periodontii, a Gram-negative, anaerobic bacillus from periodontitis lesions. Microbiology 130: 185-191.

149. Lau SK, Teng JL, Leung KW, Li NK, Ng KH, et al. (2006) Bacteremia caused by Solobacterium moorei in a patient with acute proctitis and carcinoma of the cervix. Journal of clinical microbiology 44: 3031-3034.

150. Liu WJ, Xiao M, Yi J, Li Y, Kudinha T, et al. (2019) First case report of bacteremia caused by solobacterium moorei in china, and literature review. BMC infectious diseases 19: 730.

151. Van Craenenbroeck AH, Camps K, Zachée P, Wu KL (2011) Massilia timonae infection presenting as generalized lymphadenopathy in a man returning to belgium from nigeria. Journal of clinical microbiology 49: 2763-2765.

152. Bell ME, Bernard KA, Harrington SM, Patel NB, Tucker TA, et al. (2016) Lawsonella clevelandensis gen. nov., sp. nov., a new member of the suborder corynebacterineae isolated from human abscesses. International journal of systematic and evolutionary microbiology 66: 2929-2935.

153. Limb D (2019) Proprionibacterium acnes in shoulder surgery. Orthopaedics and Trauma 33: 188-191.

154. Dubourg G, Sankar S, Rathored J, Lagier JC, Robert C, et al. (2016) Noncontiguous finished genome sequence and description of nocardioides massiliensis sp. nov. gd13t. New microbes and new infections 10: $47-57$.

155. Hussein K, Savin Z, Shani L, Dickstein Y, Geffen Y, et al. (2014) Infective endocarditis caused by finegoldia magna following aortic dissection repair: a case report and data evaluation. The American journal of case reports 15: 554 .

156. Yuan M, Zhang W, Dai S, Wu J, Wang Y, et al. (2009) Deinococcus gobiensis sp. nov., an extremely radiation-resistant bacterium. International journal of systematic and evolutionary microbiology 59: $1513-1517$.

157. Doronina N, Kaparullina E, Trotsenko YA (2011) Methylovorus menthalis, a novel species of aerobic obligate methylobacteria associated with plants. Microbiology 80: 713 .

158. Cai H, Wang Y, Xu H, Yan Z, Jia B, et al. (2015) Niveispirillum cyanobacteriorum sp. nov., a nitrogen-fixing bacterium isolated from cyanobacterial aggregates in a eutrophic lake. International journal of systematic and evolutionary microbiology 65: 2537-2541. 
Table 2: Human lung metagenome from a patient in Wuhan (PRJNA603194) showing most expressed proteins from Prevotella. Ribosomal proteins are not shown. These are raw read counts. Elongation factors proteins seem to be playing a key role in the virulence.

\begin{tabular}{|c|c|c|}
\hline Accid & Description & Counts \\
\hline WP_009012371.1 & elongation factor Tu & 6405 \\
SNR97511.1 & ATP-dependent Clp protease ATP-binding subunit ClpB & 4960 \\
WP_009012398.1 & elongation factor G & 4716 \\
SNR93756.1 & molecular chaperone DnaK & 4113 \\
WP_009012372.1 & transcription termination/antitermination factor NusG & 3038 \\
SNR67224.1 & hypothetical protein SAMN06265364_1044 & 2962 \\
SNS04478.1 & phosphoenolpyruvate carboxykinase (ATP) & 2815 \\
SNR80995.1 & glyceraldehyde 3-phosphate dehydrogenase & 2240 \\
SNR91480.1 & cysteine synthase A & 2145 \\
SNR94701.1 & chaperonin GroEL & 1984 \\
SNR97358.1 & pyruvate-ferredoxin/flavodoxin oxidoreductase & 1768 \\
WP_009012245.1 & energy transducer TonB & 1613 \\
WP_004361631.1 & DNA-directed RNA polymerase subunit alpha & 1610 \\
SNR93143.1 & DNA-directed RNA polymerase subunit beta' & 1596 \\
SNR97473.1 & Pyruvate phosphate dikinase, PEP/pyruvate binding domain & 1533 \\
SNR93835.1 & Outer membrane protein OmpA & 1488 \\
WP_089365394.1 & peroxiredoxin & 1483 \\
SNS00213.1 & ATP-dependent Clp protease ATP-binding subunit ClpC & 1437 \\
SNR60000.1 & preprotein translocase subunit SecA & 1386 \\
SNR84878.1 & hypothetical protein SAMN06265364_11429 & 1317 \\
WP_089366830.1 & translation initiation factor IF-3 & 1278 \\
SNR68043.1 & Biopolymer transport protein ExbD/TolR & 1242 \\
SNR68055.1 & Biopolymer transport protein ExbD/TolR & 1169 \\
WP_009010992.1 & elongation factor Ts & 1156 \\
\hline
\end{tabular}


Table 3: Bacterial secondary infections in a familial cluster of pneumonia indicating person-toperson transmission [121] Many more species, just listed top 30 here.

\begin{tabular}{|c|c|c|c|}
\hline NReads & Bacteria & Type & Diseases \\
\hline 16594 & Lautropia & FAC-ANE & oral cavities of HIV-infected children [122] \\
\hline 14330 & Cutibacterium & anaerobic & chronic blepharitis and endophthalmitis, \\
\hline 9618 & Escherichia & FAC-ANE & \\
\hline 5558 & Haemophilus & FAC-ANE & pneumonia, meningitis and bloodstream infection \\
\hline 4649 & Scytonema & cyanobacteria & \\
\hline 3798 & Hyphomicrobium & aerobic & \\
\hline 3289 & Capnocytophaga & FAC-ANE & usually occur with dog or cat bites \\
\hline 2440 & Burkholderia & aerobic & melioidosis $[123]$ \\
\hline 2098 & Variovorax & aerobic & \\
\hline 1811 & Campylobacter & aerobic & diarrhoea [13] \\
\hline 1781 & Pseudomonas & FAC-ANE & \\
\hline 1659 & Staphylococcus & FAC-ANE & Boils, impetigo, food poisoning, cellulitis, and toxic shock syndrome \\
\hline 1604 & Schaalia & aerobic & \\
\hline 1541 & Streptococci & aerobic & pharyngitis, pneumonia, sepsis, endocarditis, etc \\
\hline 1174 & Mycoplasma & Lack a cell wall & respiratory Mycoplasma pneumoniae [124] \\
\hline 1047 & Phyllobacterium & aerobic & \\
\hline 997 & Moraxella & aerobic & otitis media in infants and children [32] \\
\hline 940 & Flavobacterium & aerobic & fish pathogens \\
\hline 931 & Bacillus & FAC-ANE & Inhalation or respiratory anthrax \\
\hline 659 & Neisseria & aerobic & infection and persistence in the upper respiratory tract [125] \\
\hline 493 & Prevotella & anaerobic & aspiration pneumonia, lung abscess, pulmonary empyema, etc \\
\hline 463 & Fusobacterium & anaerobic & periodontal, tonsillitis, peritonsillar abscess, etc \\
\hline 358 & Veillonella & anaerobic & rare cases of meningitis, osteomyelitis, and periodontal disease \\
\hline 328 & Cupriavidus & aerobic & Infection in $87 \mathrm{yr}$ Chinese man [126] \\
\hline 325 & Corynebacterium & aerobic & diphtheria toxin $[42]$ \\
\hline 318 & Sphingomonas & aerobic & \\
\hline 314 & Micrococcus & aerobic & anaphylactoid [127] \\
\hline 307 & Loriellopsis & cyanobacteria & \\
\hline 297 & Calothrix & cyanobacteria & \\
\hline 281 & Lysinibacillus & & Sepsis [128] \\
\hline 278 & Methylobacterium & aerobic & opportunistic pathogens in immunocompromised patients \\
\hline 277 & Treponema & $?$ & syphilis, bejel, and yaws \\
\hline
\end{tabular}


Table 4: Bacterial species identified in two patients from Wuhan: The original paper stated that 'bacterial pathogen identification was carried out by using the Metaphlan2 program, which revealed Capnocytophaga sp and Veillonella sp in sample 2 and none in sample 1, and both bacteria identified were not known for their pathogenicity' This is clearly wrong - Capnocytophaga and Lautropia are there, but there are so many other pathogenic species. Also Capnocytophaga, found in the saliva of humans, dogs and cats can be pathogenic [129]. There are many more species, just listed top 10 here.

\begin{tabular}{|c|c|c|}
\hline & Patient1 & Patient2 \\
\hline Accid: Total & SRR10903402 676694 & SRR10903401 476632 \\
\hline \hline & Bacteria/ Reads per million & Bacteria/ Reads per million \\
\hline 1 & Capnocytophaga 1195.6 & Prevotella 247 \\
2 & Streptococcus 694.4 & Lautropia 236 \\
3 & Prevotella 578.9 & Veillonella 132 \\
4 & Lautropia 512.4 & Schaalia 20.5 \\
5 & Lactobacillus 161.7 & Escherichia 17.5 \\
6 & Veillonella 157.5 & Streptococcus 16.5 \\
7 & Mycoplasma 107.1 & Campylobacter 14 \\
8 & Schaalia 81.9 & Megasphaera 4.5 \\
9 & Escherichia 49 & Acinetobacter 3.5 \\
10 & Rothia 37.8 & Actinomyces 3.5 \\
\hline
\end{tabular}


Table 5: Bacterial load is much higher than SARS-Cov2 load in five patients at the early stage of the Wuhan seafood market pneumonia virus outbreak: PM=per million. Number of reads analyzed: patient1 $=11841722$, pat $2=12882084$, pat3 $=12041947$, pat4 $=13333138$, pat $5=23201546$. Pseudomonas is a definite secondary infection in patient1, while patient5 seems to have the least bacterial load. Patient 4 has the most viral load, otherwise viral load is quite low, just like in the patient from Brazil [130], explaining the high false negatives. As in all previous studies, Prevotella seems to be a common and abundant presence in all patients.

\begin{tabular}{|c|c|c|c|c|c|c|c|c|c|}
\hline Patient1 & $\mathrm{PM} /$ total & Patient2 & $\mathrm{PM} /$ total & Patient3 & $\mathrm{PM} /$ total & Patient4 & $\mathrm{PM} /$ total & Patient5 & $\mathrm{PM} /$ total \\
\hline Pseudomonas & $1529 / 18047$ & Prevotella & $125 / 1617$ & Sphingomonas & $351 / 4213$ & Capnocytophaga & $25 / 333$ & Neisseria & $11 / 260$ \\
\hline Sphingomonas & $1166 / 13766$ & Pseudomonas & $61 / 790$ & Prevotella & $157 / 1892$ & Veillonella & $18 / 250$ & Capnocytophaga & $4 / 113$ \\
\hline Clostridium & $400 / 4720$ & Streptococcus & $30 / 390$ & Pseudomonas & $141 / 1696$ & Streptococcus & $5 / 79$ & AlloPrevotella & $1 / 43$ \\
\hline Sphingobacterium & $326 / 3851$ & Clostridium & $28 / 370$ & Clostridium & $47 / 564$ & Cardiobacterium & $5 / 72$ & Prevotella & $1 / 38$ \\
\hline Lactobacillus & $244 / 2885$ & Haemophilus & $18 / 236$ & Escherichia & $36 / 440$ & Prevotella & $3 / 51$ & Haemophilus & $1 / 32$ \\
\hline Anaerocolumna & $217 / 2564$ & Lactobacillus & $14 / 181$ & Sphingobacterium & $32 / 386$ & Neisseria & $3 / 44$ & Coxiella & $1 / 26$ \\
\hline Delftia & $176 / 2084$ & Actinobacillus & $12 / 155$ & Streptococcus & $31 / 376$ & Schaalia & $2 / 33$ & Veillonella & $0 / 20$ \\
\hline Paenibacillus & $170 / 2006$ & Anaerocolumna & $10 / 133$ & Neochlamydia & $27 / 334$ & Ottowia & $1 / 14$ & Streptococcus & $0 / 17$ \\
\hline Neochlamydia & $168 / 1987$ & Escherichia & $10 / 129$ & Lactobacillus & $21 / 262$ & Coxiella & $0 / 13$ & Nocardioides & $0 / 16$ \\
\hline Methylorubrum & $150 / 1772$ & Neisseria & $9 / 118$ & Delftia & $19 / 232$ & Lautropia & $0 / 11$ & Campylobacter & $0 / 13$ \\
\hline Lysinibacillus & $148 / 1750$ & Delftia & $7 / 101$ & Methylorubrum & $17 / 206$ & Campylobacter & $0 / 10$ & Fusobacterium & $0 / 12$ \\
\hline Pelomonas & $123 / 1461$ & Paenibacillus & $7 / 99$ & Haemophilus & $17 / 204$ & Brachymonas & $0 / 8$ & Paracoccus & $0 / 12$ \\
\hline Prevotella & $106 / 1256$ & Sphingomonas & $7 / 99$ & Anaerocolumna & $16 / 199$ & Pseudomonas & $0 / 8$ & Pseudomonas & $0 / 11$ \\
\hline Chryseobacterium & $97 / 1155$ & Lysinibacillus & $6 / 78$ & Paenibacillus & $12 / 151$ & Eikenella & $0 / 7$ & Cardiobacterium & $0 / 10$ \\
\hline SARS-Cov2 & $78 / 923$ & SARS-Cov2 & $30 / 396$ & SARS-Cov2 & $18 / 222$ & SARS-Cov2 & $362 / 4821$ & SARS-Cov2 & $19 / 454$ \\
\hline
\end{tabular}


Table 6: Bacterial reads in a patient from Cambodia/Peru: And among the first 20 such species, all, barring one or two (highlighted in bold), are either obligate-anaerobic or facultatively anaerobic (FAC-ANE). In fact, its the percentage of obligate-anaerobic that's more important, they seem to have colonized the lungs, disrupting the homeostasis with aerobic bacteria [17].

\begin{tabular}{|c|c|c|c|c|}
\hline & Reads & Bacteria & Description & Disease \\
\hline \multirow{20}{*}{ Cambodia } & 135955 & Prevotella & obligateanaerobic & aspiration pneumonia, lung abscess, pulmonary empyema, etc $[12,28]$ \\
\hline & 134787 & Veillonella & obligateanaerobic & rare cases of meningitis, osteomyelitis, and periodontal disease \\
\hline & 103875 & Haemophilus & FAC-ANE & pneumonia, meningitis and bloodstream infection [131] \\
\hline & 95675 & Neisseria & FAC-ANE & infection and persistence in the upper respiratory tract [125] \\
\hline & 51421 & Capnocytophaga & FAC-ANE & usually occur with dog or cat bites \\
\hline & 45859 & Streptococcus & FAC-ANE & pneumonia, bacteremia $[29]$ \\
\hline & 34820 & Fusobacterium & obligateanaerobic & periodontal, tonsillitis, peritonsillar abscess, etc \\
\hline & 23228 & Leptotrichia & FAC-ANE & Endocarditis [31] \\
\hline & 21831 & Actinobacillus & FACANE & wooden tongue disease [132] \\
\hline & 19160 & Morococcus & aerobic & periodontal $[133]$ \\
\hline & 15051 & Campylobacter & aerobic & diarrhoea $[13]$ \\
\hline & 11195 & Parabacteroides & obligateanaerobic & {$[134]$} \\
\hline & 10252 & Rodentibacter & FACANE & {$[135]$} \\
\hline & 9626 & Aggregatibacter & FACANE & endocarditis, periodontal infection $[136]$ \\
\hline & 9287 & Bacteroides & obligateanaerobic & 'genus Bacteroides have the most antibiotic resistance mechanisms' [33] \\
\hline & 8446 & Porphyromonas & FAC-ANE & periodontal disease $[137]$ \\
\hline & 6415 & Pasteurella & FACANE & respiratory disease [138] \\
\hline & 3717 & Gemella & FAC-ANE & Infective Endocarditis [139] \\
\hline & 3700 & Kingella & weak FACANE & pneumonia, meningitis, ocular infections, pericarditis and peritonitis [140] \\
\hline & 3564 & Bergeriella & FACANE & {$[141]$} \\
\hline \multirow{20}{*}{ Peru } & 291478 & Veillonella & obligateanaerobic & rare cases of meningitis, osteomyelitis, and periodontal disease [142] \\
\hline & 88835 & Prevotella & obligateanaerobic & aspiration pneumonia, lung abscess, pulmonary empyema, etc [12] \\
\hline & 62091 & Fusobacterium & obligateanaerobic & periodontal, tonsillitis, peritonsillar abscess, etc $[143]$ \\
\hline & 35808 & Streptococcus & FAC-ANE & pneumonia, bacteremia $[29]$ \\
\hline & 25789 & Oribacterium & obligateanaerobic & periodontal disease [144] \\
\hline & 25636 & Porphyromonas & FAC-ANE & periodontal disease [137] \\
\hline & 25436 & Selenomonas & obligateanaerobic & periodontal disease [38] \\
\hline & 20951 & Leptotrichia & FAC-ANE & Endocarditis [31] \\
\hline & 15906 & Megasphaera & obligateanaerobic & Bacterial Vaginosis [34] \\
\hline & 13417 & Bacillus & FAC-ANE & Inhalation or respiratory anthrax \\
\hline & 13246 & Campylobacter & aerobic & diarrhoea $[13]$ \\
\hline & 10786 & Haemophilus & FAC-ANE & pneumonia, meningitis and bloodstream infection \\
\hline & 9894 & Gemella & FAC-ANE & Infective Endocarditis [139] \\
\hline & 6275 & Streptobacillus & FAC-ANE & Rat bite fever [145] \\
\hline & 5697 & Granulicatella & FAC-ANE & Bacterascites $[146]$ \\
\hline & 4573 & Bacteroides & obligateanaerobic & 'genus Bacteroides have the most antibiotic resistance mechanisms' [33] \\
\hline & 4505 & Stomatobaculum & obligateanaerobic & {$[147]$} \\
\hline & 4351 & Centipeda & obligateanaerobic & Periodontitis Lesions [148] \\
\hline & 4297 & Dolosigranulum & FAC-ANE & multiple sclerosis [47] \\
\hline & 3820 & Solobacterium & obligateanaerobic & Bacteremia $[149,150]$ \\
\hline
\end{tabular}


Table 7: Bacterial reads in a patient from Brazil While Haemophilus, Lautropia and Prevotella are common to other metagenomes, Cellvibrio and Massilia are two unique species found in the Brazilian patient.

\begin{tabular}{|c|c|c|c|}
\hline NReads & Bacteria & Type & Diseases \\
\hline 1747 & Haemophilus & FAC-ANE & pneumonia, meningitis and bloodstream infection \\
1634 & Lautropia & FAC-ANE & oral cavities of HIV-infected children [122] \\
1094 & Prevotella & anaerobic & aspiration pneumonia, lung abscess, pulmonary empyema, etc \\
726 & Escherichia & FAC-ANE & \\
714 & Schaalia & aerobic & robust capacity for plant polysaccharide degradation \\
589 & Cellvibrio & aerobic & pharyngitis, pneumonia, sepsis, and endocarditis \\
561 & Streptococcus & aerobic & chronic blepharitis and endophthalmitis, \\
446 & Cutibacterium & anaerobic & $?$ \\
434 & Massilia & $?$ & Lymphadenopathy [151] \\
368 & Pseudomonas & FAC-ANE & \\
\hline
\end{tabular}


Table 8: Bacterial reads in a patient from Bangladesh (PRJNA633241) While, bacterial load is low (and this might be due to removal of reads), it corroborates the anaerobic domination with a novel anaerobic bacteria - Lawsonella clevelandensis - being implicated. FAC-ANE =facultatively anaerobic (aerobic, but capable of switching to fermentation if oxygen is absent).

\begin{tabular}{|c|c|c|c|}
\hline NReads & Bacteria & Type & Diseases \\
\hline 57 & Staphylococcus & FAC-ANE & Boils, impetigo, food poisoning, cellulitis, and toxic shock syndrome \\
\hline 41 & Lawsonella & anaerobic & found in abscesses $[152]$ \\
\hline 27 & Corynebacterium & aerobic & diphtheria toxin $[42]$ \\
\hline 15 & Cutibacterium & obligateanaerobic & chronic blepharitis and endophthalmitis [153] \\
\hline 14 & Pseudomonas & FAC-ANE & \\
\hline 10 & Escherichia & FAC-ANE & \\
\hline 6 & Haemophilus & FAC-ANE & pneumonia, meningitis and bloodstream infection [131] \\
\hline 5 & Lautropia & FAC-ANE & oral cavities of HIV-infected children [122] \\
\hline 5 & Nocardioides & aerobic & novel species $[154]$ \\
\hline 3 & Finegoldia & anaerobic & endocarditis [155] \\
\hline 3 & Sphingomonas & aerobic & \\
\hline 3 & Streptococcus & FAC-ANE & pneumonia, bacteremia $[29]$ \\
\hline 3 & Veillonella & obligateanaerobic & rare cases of meningitis, osteomyelitis, and periodontal disease [27] \\
\hline 2 & Bacillus & FAC-ANE & Inhalation or respiratory anthrax \\
\hline 2 & Basilea & aerobic & new genus found in lung of a parakeet in Basel,Switzerland [?] \\
\hline 2 & Deinococcus & aerobic & the most radiation-resistant bacteria $[156]$ \\
\hline 2 & Lachnoanaerobaculum & anaerobic & new genus $[39]$ \\
\hline 2 & Methylovorus & aerobic & novel species $[157]$ \\
\hline 2 & Niveispirillum & cyanobacteria & nitrogen-fixing bacterium [158] \\
\hline 2 & Porphyromonas & obligateanaerobic & periodontal disease $[36]$ \\
\hline 2 & Scytonema & cyanobacteria & \\
\hline 1 & Prevotella & obligateanaerobic & aspiration pneumonia, lung abscess, pulmonary empyema, etc $[12,28]$ \\
\hline
\end{tabular}


Table 9: Bacterial reads in sequencing data from nasopharyngeal swab (NSPH) or gut Submitted by Emory University School of Medicine, Georgia. Prevotella/Streptococcus and other anaerobes colonize the metagenome, corroborating the hypothesis that SARS-Cov2 is enabling anaerobes. The bacterial load is quite high, the first five species comprise $70 \%$ of the load.

\begin{tabular}{|c|c|c|c|c|}
\hline & PerMillion & Bacteria & Type & Diseases \\
\hline $\mathrm{NSPH}$ & $\begin{array}{c}218827 \\
202862 \\
191362 \\
66431 \\
33327 \\
23896 \\
23534 \\
15448 \\
12172 \\
9603 \\
8482 \\
7103 \\
6706 \\
6689 \\
4793\end{array}$ & $\begin{array}{c}\text { Veillonella } \\
\text { Prevotella } \\
\text { Streptococcus } \\
\text { Schaalia } \\
\text { Atopobium } \\
\text { Leptotrichia } \\
\text { Moraxella } \\
\text { Bacteroides } \\
\text { Actinomyces } \\
\text { Megasphaera } \\
\text { Porphyromonas } \\
\text { Campylobacter } \\
\text { Fusobacterium } \\
\text { Selenomonas } \\
\text { Lachnoanaerobaculum }\end{array}$ & $\begin{array}{c}\text { obligateanaerobic } \\
\text { obligateanaerobic } \\
\text { FAC-ANE } \\
\text { FAC-ANE } \\
\text { anaerobic } \\
\text { FAC-ANE } \\
\text { aerobic } \\
\text { obligateanaerobic } \\
\text { FAC-ANE } \\
\text { obligateanaerobic } \\
\text { obligateanaerobic } \\
\text { aerobic } \\
\text { obligateanaerobic } \\
\text { obligateanaerobic } \\
\text { anaerobic }\end{array}$ & $\begin{array}{c}\text { rare cases of meningitis, osteomyelitis, and periodontal disease }[27] \\
\text { aspiration pneumonia, lung abscess, pulmonary empyema, etc }[12,28] \\
\text { pneumonia, bacteremia }[29] \\
\text { similar to Actinomyces, alimentary tract diseases [30] } \\
\text { Bacterial vaginosis }[24] \\
\text { Endocarditis }[31] \\
\text { otitis media in infants and children [32] } \\
\text { 'genus Bacteroides have the most antibiotic resistance mechanisms' [33] } \\
\text { alimentary tract diseases [30] } \\
\text { Bacterial Vaginosis }[34,35] \\
\text { periodontal disease }[36] \\
\text { diarrhoea }[13] \\
\text { periodontal, tonsillitis, peritonsillar abscess, etc }[37] \\
\text { periodontal disease }[38] \\
\text { new genus }[39]\end{array}$ \\
\hline Gut & $\begin{array}{c}104097 \\
8612 \\
6383 \\
3888 \\
3307 \\
2968 \\
1365 \\
787 \\
593 \\
545 \\
414 \\
317 \\
313 \\
310 \\
286\end{array}$ & $\begin{array}{c}\text { Enterococcus } \\
\text { Escherichia } \\
\text { Corynebacterium } \\
\text { Klebsiella } \\
\text { Salmonella } \\
\text { Shigella } \\
\text { Dolosigranulum } \\
\text { Staphylococcus } \\
\text { Carnobacterium } \\
\text { Bacillus } \\
\text { Lactobacillus } \\
\text { Streptococcus } \\
\text { Aerococcus } \\
\text { Erwinia } \\
\text { Sphingomonas }\end{array}$ & $\begin{array}{c}\text { FAC-ANE } \\
\text { FAC-ANE } \\
\text { aerobic } \\
\text { FACANE } \\
\text { FAC-ANE } \\
\text { FAC-ANE } \\
\text { FAC-ANE } \\
\text { FAC-ANE } \\
\text { anaerobic } \\
\text { FAC-ANE } \\
\text { FACANE } \\
\text { FAC-ANE } \\
\text { aerobic } \\
\text { FAC-ANE } \\
\text { aerobic }\end{array}$ & $\begin{array}{c}\text { urinary tract infections; intraabdominal [40] } \\
\text { cholecystitis, bacteremia, cholangitis, urinary tract infection [41] } \\
\text { diphtheria toxin [42] } \\
\text { pneumoni [43] and intestinal colonization [44] } \\
\text { typhoid [45] } \\
\text { eading cause of diarrhoeal death among children [46] } \\
\text { multiple sclerosis [47] } \\
\text { Boils, impetigo, food poisoning, cellulitis, and toxic shock syndrome } \\
\text { frequently isolated from natural environments and foods [48] } \\
\text { Inhalation or respiratory anthrax } \\
\text { mutualistic beneficial relationship with the human body, [49] } \\
\text { pneumonia, bacteremia [29] } \\
\text { Urinary tract infection [50] } \\
\text { dermohypodermitis and bactaeremia [51] }\end{array}$ \\
\hline
\end{tabular}


Table 10: Controls using healthy samples from BALF and nasopharyngeal does not show homeostasis disruption: Study1:Human respiratory tract metagenome (BALF) submitted by WeHealthGene Co., Ltd , Accid:PRJNA431097. Study2: To test the interaction between the human nasal microbiome shifts and human health, Renji Hosptial, China Accid:PRJNA508588. Study1 was on children. Study2 was on children, young adults and seniors. The anaerobes implicated in Covid19 are almost absent here - I have highlighted Prevotella. There is one technical detail - these healthy studies are using $16 \mathrm{~S}$ rRNA sequencing, while all Covid19 studies are not (ie they sequence everything). But rRNA is the most predominant RNA - and the correlation should hold quite well.

\begin{tabular}{|c|c|c|c|c|c|c|}
\hline Study1 & 1 & 2 & 3 & 4 & 5 & 6 \\
\hline & $\begin{array}{c}\text { Mycoplasma-41365 } \\
\text { Acinetobacter-16545 } \\
\text { Streptococcus-2872 } \\
\text { Bacillus-930 } \\
\text { Haemophilus-742 } \\
\text { Chlamydia-712 } \\
\text { Pseudomonas-674 } \\
\text { Staphylococcus-654 } \\
\text { Bifidobacterium-426 } \\
\text { Rubrobacter-360 }\end{array}$ & $\begin{array}{c}\text { Acinetobacter-23776 } \\
\text { Brevundimonas- } 8581 \\
\text { Paracoccus-5864 } \\
\text { Bifidobacterium-5025 } \\
\text { Sphingomonas-1861 } \\
\text { Bacillus-1774 } \\
\text { Streptococcus-1086 } \\
\text { Massilia-1054 } \\
\text { Pseudomonas-763 } \\
\text { Rubrobacter-609 }\end{array}$ & $\begin{array}{c}\text { Mycoplasma-34316 } \\
\text { Haemophilus-5999 } \\
\text { Staphylococcus-5886 } \\
\text { Streptococcus- } 4189 \\
\text { Prevotella-1936 } \\
\text { Lactobacillus-1409 } \\
\text { Schaalia-1384 } \\
\text { Bacillus-934 } \\
\text { Sphingomonas-573 } \\
\text { Pectobacterium- } 436 \\
\end{array}$ & $\begin{array}{c}\text { Staphylococcus- } 49192 \\
\text { Mycoplasma- } 24481 \\
\text { Streptococcus-963 } \\
\text { Haemophilus- } 278 \\
\text { Lactobacillus-210 } \\
\text { Bacillus-116 } \\
\text { Prevotella-37 } \\
\text { Gemella-34 } \\
\text { Halomonas-33 } \\
\text { Pseudomonas-33 }\end{array}$ & $\begin{array}{c}\text { Haemophilus-37048 } \\
\text { Streptococcus-19781 } \\
\text { Bergeriella-6611 } \\
\text { Staphylococcus-3904 } \\
\text { Mycoplasma-1361 } \\
\text { Lactobacillus-637 } \\
\text { Pelomonas-555 } \\
\text { Neisseria-506 } \\
\text { Pectobacterium-308 } \\
\text { Bacteroides-275 }\end{array}$ & $\begin{array}{c}\text { Acinetobacter-2404 } \\
\text { Streptococcus-849 } \\
\text { Bacillus-470 } \\
\text { Haemophilus-409 } \\
\text { Stenotrophomonas-350 } \\
\text { Mycoplasma-168 } \\
\text { Pseudomonas-123 } \\
\text { Brevundimonas-119 } \\
\text { Lactobacillus-90 } \\
\text { Massilia-68 }\end{array}$ \\
\hline Study2 & Child1 & Child2 & Young adult1 & Young adult2 & Senior1 & Senior2 \\
\hline & $\begin{array}{c}\text { Bacteroides-17230 } \\
\text { Bifidobacterium-10104 } \\
\text { Clostridium-9924 } \\
\text { Faecalibacterium-6294 } \\
\text { Catenisphaera-4375 } \\
\text { Eubacterium-4176 } \\
\text { Staphylococcus-4125 } \\
\text { Pectobacterium-3646 } \\
\text { Ruminococcus-3467 } \\
\text { Lactobacillus-3312 }\end{array}$ & $\begin{array}{c}\text { Bacteroides-22948 } \\
\text { Bifidobacterium-12673 } \\
\text { Clostridium-11092 } \\
\text { Faecalibacterium-7055 } \\
\text { Catenisphaera-4777 } \\
\text { Lactobacillus-4572 } \\
\text { Eubacterium-4489 } \\
\text { Pectobacterium-4453 } \\
\text { Ruminococcus-3976 } \\
\text { Staphylococcus-3386 }\end{array}$ & $\begin{array}{c}\text { Staphylococcus-50233 } \\
\text { Bacteroides- } 11224 \\
\text { Bifidobacterium-9080 } \\
\text { Corynebacterium-9068 } \\
\text { Anaerococcus- } 6077 \\
\text { Clostridium-5891 } \\
\text { Faecalibacterium-3739 } \\
\text { Pectobacterium-2717 } \\
\text { Eubacterium-2686 } \\
\text { Ruminococcus-2233 }\end{array}$ & $\begin{array}{c}\text { Staphylococcus-69154 } \\
\text { Corynebacterium-24903 } \\
\text { Bacteroides-7288 } \\
\text { Bifidobacterium-4123 } \\
\text { Anaerococcus-3214 } \\
\text { Escherichia- } 2942 \\
\text { Pseudomonas-2930 } \\
\text { Clostridium-2901 } \\
\text { Faecalibacterium-2182 } \\
\text { Eubacterium-1418 }\end{array}$ & $\begin{array}{c}\text { Bacteroides-14501 } \\
\text { Bifidobacterium-8604 } \\
\text { Clostridium-7483 } \\
\text { Faecalibacterium-6625 } \\
\text { Eubacterium-4107 } \\
\text { Ruminococcus-3433 } \\
\text { Collinsella-3142 } \\
\text { Lactobacillus-2640 } \\
\text { Pseudomonas-2479 } \\
\text { Flavonifractor-2456 }\end{array}$ & $\begin{array}{c}\text { Bacteroides-16653 } \\
\text { Clostridium-10723 } \\
\text { Bifidobacterium-9937 } \\
\text { Faecalibacterium-8373 } \\
\text { Eubacterium-5585 } \\
\text { Ruminococcus-4503 } \\
\text { Pectobacterium-3778 } \\
\text { Collinsella-3747 } \\
\text { Lactobacillus-3538 } \\
\text { Prevotella- } 2721\end{array}$ \\
\hline
\end{tabular}


Table 11: Highly expressed mRNA in deceased 74 yr old Covid19 lung sample clearly shows bacterial infection: IFITM2- Interferon-induced transmembrane protein have viral roles, but also play a role "in restriction of M. tuberculosis infection" [55]. Another study found "differences in the representation of the genus Prevotella within the Prevotellaceae family, showing significant increase in abundance' in IFITM3deficient and knockout mice [56]. Ferritin is also high, it is a well-known marker - "lung pathogens such as $\mathrm{H}$. influenza have developed strategies to acquire iron by using iron-containing human proteins such as tranferrin, lactoferrin, haemoglobin and ferritin" [57]. Also, S100 calcium binding proteins (several figure in the list), along with Procalcitonin (and CRP) which are elevated in many Covid19 patients, are used as marker for bacterial infections [58]

\begin{tabular}{|c|c|c|c|c|}
\hline SL & Gene & Nreads & Accid & Description \\
\hline 1. & IFITM2 & 27374 & NM_006435.2 & interferon induced transmembrane protein 2 \\
\hline 2. & FTH1 & 26438 & NM_002032.3 & ferritin heavy chain 1 \\
\hline 3. & ACTB & 25104 & NM_001101.5 & actin beta \\
\hline 4. & $\mathrm{~B} 2 \mathrm{M}$ & 20225 & XM_005254549.3 & beta-2-microglobulin \\
\hline 5. & SRGN & 18745 & XM_024448066.1 & serglycin \\
\hline 6. & CCL4 & 18665 & NM_002984.4 & C-C motif chemokine ligand 4 \\
\hline 7. & SOD2 & 18333 & NM_000636.4 & superoxide dismutase 2 \\
\hline 8. & CCL2 & 14536 & NM_002982.4 & C-C motif chemokine ligand 2 \\
\hline 9. & FCER1G & 12364 & NM_004106.2 & $\mathrm{Fc}$ fragment of $\mathrm{IgE}$ receptor $\mathrm{Ig}$ \\
\hline 10. & SAT1 & 12328 & XM_024452421.1 & spermidine/spermine N1-acetyltransferase 1 \\
\hline 11. & CCL4L1 & 12315 & NM_207007.3 & C-C motif chemokine ligand 4 like 1 \\
\hline 12. & IFITM3 & 11558 & NM_021034.3 & interferon induced transmembrane protein 3 \\
\hline 13. & CCL3L3 & 10911 & NM_001001437.4 & C-C motif chemokine ligand 3 like 3 \\
\hline 14. & IL1RN & 10326 & XM_005263661.4 & interleukin 1 receptor antagonist \\
\hline 15. & IFI6 & 9119 & XM_024446207.1 & interferon alpha inducible protein 6 \\
\hline 16 . & HLA-A & 8583 & XM_024452558.1 & major histocompatibility complex, class I, A \\
\hline 17. & FTL & 8443 & XM_024451447.1 & ferritin light chain \\
\hline 18. & CD74 & 8346 & XM_017010090.2 & CD74 molecule \\
\hline 19. & LOC112268284 & 7955 & XM_024452143.1 & basic proline-rich protein-like \\
\hline 20. & SELL & 7900 & NM_000655.5 & selectin $\mathrm{L}$ \\
\hline 21. & HLA-B & 7428 & NM_005514.8 & major histocompatibility complex, class I, B \\
\hline 22 . & S100A8 & 7340 & NM_002964.5 & S100 calcium binding protein A8 \\
\hline 23. & TPT1 & 7008 & NM_003295.3 & tumor protein, translationally-controlled 1 \\
\hline 24. & CXCL8 & 6434 & NM_000584.4 & C-X-C motif chemokine ligand 8 \\
\hline 25. & CCL4L2 & 5688 & NM_001291475.2 & C-C motif chemokine ligand 4 like 2 \\
\hline 26. & EEF1A1 & 5364 & NM_001402.6 & eukaryotic translation elongation factor 1 alpha 1 \\
\hline 27. & BCL2A1 & 5358 & NM_004049.4 & BCL2 related protein A1 \\
\hline 28. & NAMPT & 5167 & NM_005746.3 & nicotinamide phosphoribosyltransferase \\
\hline 29. & CCL3 & 5101 & NM_002983.3 & C-C motif chemokine ligand 3 \\
\hline 30. & S100A11 & 5008 & NM_005620.2 & S100 calcium binding protein A11 \\
\hline 31. & IL1B & 4896 & XM_017003988.2 & interleukin 1 beta \\
\hline 32. & PLEK & 4878 & NM_002664.3 & pleckstrin \\
\hline 33. & HBA2 & 4652 & NM_000517.6 & hemoglobin subunit alpha 2 \\
\hline 34. & IL2RG & 4349 & NM_000206.2 & interleukin 2 receptor subunit gamma \\
\hline 35. & S100A9 & 4263 & NM_002965.4 & S100 calcium binding protein A9 \\
\hline 36. & TIMP1 & 3933 & XM_017029766.2 & TIMP metallopeptidase inhibitor 1 \\
\hline 37. & IFIT3 & 3918 & NM_001549.6 & interferon induced protein with tetratricopeptide repeats 3 \\
\hline 38. & H3F3B & 3896 & NM_005324.5 & H3 histone family member 3B \\
\hline 39. & ALOX5AP & 3837 & XM_017020522.2 & arachidonate 5 -lipoxygenase activating protein \\
\hline 40. & PFN1 & 3783 & XM_017024761.1 & profilin 1 \\
\hline 41. & IFITM1 & 3501 & NM_003641.4 & interferon induced transmembrane protein 1 \\
\hline 42. & OAS3 & 3429 & XM_017019363.2 & 2-5-oligoadenylate synthetase 3 \\
\hline 43. & CXCL10 & 3423 & NM_001565.4 & C-X-C motif chemokine ligand 10 \\
\hline 44. & CCL8 & 3322 & NM_005623.3 & C-C motif chemokine ligand 8 \\
\hline 45. & MARCKS & 3279 & NM_023009.7 & MARCKS like 1 \\
\hline
\end{tabular}

